\title{
Demographic survey of vaginitis prevalence in district Swabi, Khyber Pakhtunkhwa
}

\author{
Muhammad $^{1 *}$, Nabeela ${ }^{1}$, Saadat Mehmood ${ }^{1}$, Sobia Zaib $^{1}$ and \\ Muhammad Rizwan ${ }^{2}$ \\ 1. Department of Microbiology, University of Swabi, Khyber Pakhtunkhwa-Pakistan \\ 2. Department of Microbiology and Biotechnology, Abasyn University Peshawar, Khyber Pakhtunkhwa- \\ Pakistan \\ *Corresponding author's email: $\underline{\text { muhammad@uoswabi.edu.pk }}$ \\ Citation \\ Muhammad, Nabeela, Saadat Mehmood, Sobia Zaib and Muhammad Rizwan. Demographic survey of vaginitis \\ prevalence in district Swabi, Khyber Pakhtunkhwa. Pure and Applied Biology. Vol. 7, Issue 1, pp133-137. \\ http://dx.doi.org/10.19045/bspab.2018.70016
}

\begin{tabular}{llll}
\hline \hline Received: 23/10/2017 & Revised: 22/12/2017 & Accepted: 28/12/2017 & Online First: 10/01/2018 \\
\hline \hline
\end{tabular}

\section{Abstract}

Vaginitis is an important infection of females cause inflammation of vagina and vulva. It also causes discharge, itching and pain. Vaginitis is of three kinds, including trichomoniasis, bacterial vaginosis and vaginal candidiasis or vaginal yeast. The current questionnaire based study was conducted at Bacha khan medical complex (BMC) Swabi from March 2016 to May 2016. During the study high number of cases 22 (36\%) were recorded in age group B: 21 25 years while the lowest ratio of cases $2(3 \%)$ were recorded in age group G: $46-50$ years. Also it was further noted that married females were more infected than non-married, i.e. $54(87 \%)$ and $8(13 \%)$ respectively. The mentioned infection is considering as a confidential issue of female in Pakhtun society. Awareness and further study is recommended regarding vaginitis.

Keywords: Demographic survey; District Swabi; Vaginitis

\section{Introduction}

Vaginitis also known's as vaginal infection is an inflammation of vagina and possibly vulva $[1,2]$.It results in discharge, itching and pain [2].Often associated with irritation of vulva. Infected women also asymptomatic usually after infection [3]. Vaginitis has three main kinds, i.e. trichomoniasis, bacterial vaginosis and vaginal candidiasis or vaginal yeast [4].

An approximate 37 lac individuals in the US affected by trichomonal vaginitis caused by protozoan, Trichomonas vaginalis is a sexually transmitted disease[5].The incidence of Trichomonas vaginalis infection varies among sexually active women, usually 5\% approximation amid women in family planning clinics,
$10 \%$ between women using internet based screening program and most high rank among confined women $37 \%$ [6-9]. Scientific signs and symptoms for vaginitis and vaginal discharge is estimated that majority are found asymptomatic [10-12]. Problems related to untreated Trichomonas vaginalis including serious health significances, infertility, pelvic inflammatory disease, low birth weight and increase possibility of HIV [13-17].

Bacterial vaginosis polymicrobial apparent vaginal infection having loss of lactobacilli and over growth of anaerobes [18]. Infection caused by multiplication of organisms including Gardnerella vaginalis, Mobiluncus species, Mycoplasma hominis and Peptostrepto coccus species [19]. In 
Bacterial vaginosis no polymer nuclear cells are present in vaginal discharge but normal vaginal flora decreases and vaginal $\mathrm{pH}$ increase leads to overgrowth of $G$. vaginalis and vaginal anaerobic bacteria cause white or grey discharge with amine smells. The occurrences of bacterial vaginosis are problematic since one third to three residences women affected are asymptomatic [20].In addition reports on bacterial vaginosis occurrences stated that the infection is found as 15-19\% in gynaecological patients, $10-80 \%$ in pregnant patients and $20-41 \%$ in sexually transmitted clinics patients [21].

The most common gynaecological problem in pre pubertal girls is vulvovaginitis. Majority cases of vulvovaginal candidiasis caused by candida albicans. The infection vaginal yeast is actually not a sexually transmitted disease. Mostly at least once in the life span of all adult women, face genital yeast infection [22, 23]. Yeast infection by over growth of usually growing fungi in vagina generates unlikeable symptoms. Normally growing bacteria usually control yeast infection in the body. Yeast over grows if normal balance of microorganisms disturbed. When imbalance occurs, women's own natural bacteria permit fungal infection [24]. The vaginal Health Organization recommended that yeast infection prohibited in most cases; done by keeping vaginal area dry after shower, avoid using fit underwear, tight fitting jeans and change wet bathing suits $[25,26]$.

\section{Materials and methods}

The present study was conducted at Bacha khan medical complex (BMC) Swabi, from March 2016 to May 2016. The ethical permission was granted by the higher authority of the hospital. A questionnaire based study was conducted conformed by the clinical diagnosis reports (vaginal examination). The obtained data of 62 patients were analyzed and entered into Micro-soft Excel 2010 and presented in the form of demographic studies, including name of patients, date of entry, gender and age, etc.

\section{Results}

During the current study the patients were placed in various age groups including age group A: 15-20 years, age group B: 2125years, age group C: 26-30 years, age group D: $31-35$ years, age group E: $36-40$ years, age group F: 41-45 years and age group G: 46-50 years. The results shows that high number of cases $22(36 \%)$ were recorded in age group B: 21-25years followed by age group A 12(20\%), $10(17 \%)$ by age group C: $26-30$ years, $8(12 \%)$ by age group D: $31-35$ years, 4 $(6 \%)$ by age group F: 41-45 years and $2(3 \%)$ by age group G: $46-50$ years (Figure1).

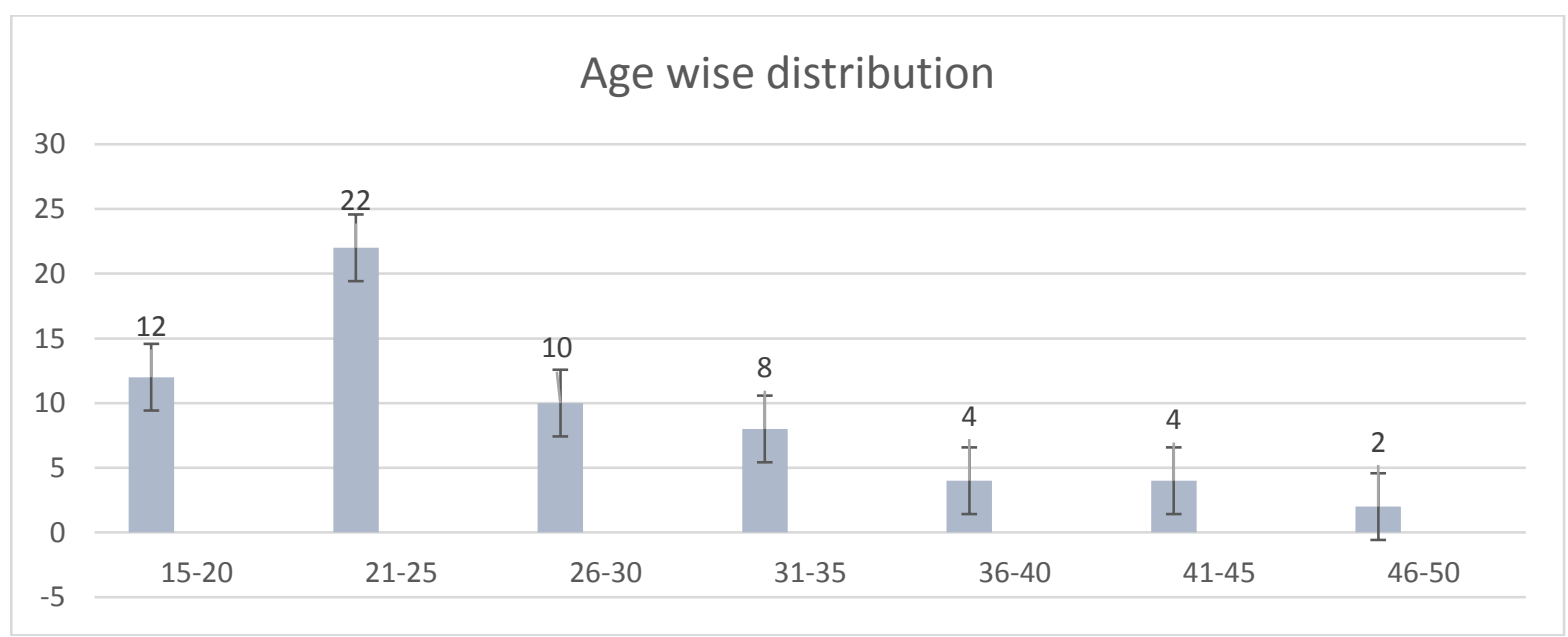

Figure 1. Age wise distribution of patients 
The data was also categorized on the basis of marital status and found that 54(87\%) women were found married while $8(13 \%)$ unmarried had vaginal infections. Similarly in infected cases $24(39 \%)$ women were recorded pregnant while $38(61 \%)$ were recorded non-pregnant. Furthermore $61 \%$ women were found infected by fungi followed by mixed and bacterial infections $19 \%$ and $18 \%$ respectively, while $2 \%$ were infected by Trichomonas (Table1).

Table 1. Demographic distribution of patients

\begin{tabular}{|l|l|l|l|}
\hline Marital status & & & \\
\hline Married & Unmarried & & \\
\hline $54(87 \%)$ & $8(13 \%)$ & & \\
\hline Pregnancy status & & & \\
\hline Pregnant & Non-pregnant & & \\
\hline $24(39 \%)$ & $38(61 \%)$ & & \\
\hline Types of infection & & & \\
\hline Bacterial infection & Fungal Infection & Trichomonas & Mixed \\
\hline $11(18 \%)$ & $38(61 \%)$ & $1(2 \%)$ & $12(19 \%)$ \\
\hline
\end{tabular}

\section{Discussion}

The results introduced the prevalence of vaginal infections among women of district Swabi, where the numbers of cases are increasing daily.In developing and nondeveloping countries it's becoming one of the major problems, pains taking as gynaecologic diseases [19]. The high rate of vaginitis infection was observed in age group 21-25,22 (36\%) which is considered as sexually active group. Venugopal et al. [27] conducted a research work in 2017 and found that vaginal infections were $(27 \%)$ in age group 26-35 and 18-25 years followed by $(23 \%)$ in age group $40-50$ and $36-40$ years. The increased prevalence in younger age groups may be due to increased sexual activity [27]. 38 (61\%) women were infected by fungi followed by mixed and bacterial infections $19 \%$ and $18 \%$ respectively. Observations in our study concise with the study of Lennox et al. [27] where $19 \%$ had mixed infections, $(64.71 \%)$ had fungal while $(35.29 \%)$ had bacterial vaginosis [28]. Our finding are concise with the study conducted by Venugopal et al. [27] who found BV in $(27 \%)$ of the patients followed by trichomoniasis (25\%), vaginal candidiasis $(22 \%)$ and shared infection (3\%)[27]. Another similar results were recorded in the study conducted by Janulaitiene et al. [29]where 119vaginal samples were processed and 29 (24.4\%) of them were categorized as BV positive[29].This is analogous to the study investigated by Koumans et al. [30] who found 29.2\% prevalence of BV [30]. In Pawanarkar and Chopra [31] readings, BV was found prevalent in $19 \%$ of womanhood like in our study [31]. In one of the research by Gupta et al. [32]a total of 139 females were investigated and vaginal infection were found in $44.6 \%$ of females as light higher than our study [32]. Nessa et al. [33] carried out a research work in 2013 in Bangladesh stated $48.1 \%$ cases of BV amid the sex workers which are also on the higher side[33]. In our study, the overall prevalence of fungal vaginitis were found to be $(35.29 \%)$ comparable to $(28.3 \%)$ of Rezaei et al., [34].Similar results were shown by Ness et a., [35] stated that $40 \%$ of the married women have bacterial vaginitis indicated that a women with sexual transmitted vaginitis from their sexual partners[35].The study concise with current study shows that54 $(87 \%)$ of the infected females have their sexual partners. The present study shows that $54(87 \%)$ of the married females were infected by vaginitis, indicated that sexual activity may frequently be a risk factor for vaginitis. The results are in agreement with the research work conducted by Chengo et al. [36] who 
reported vaginitis in $(93.6 \%)$ of married females. Similarly shown by previous studies that candida spp more likely to thrive during individual sexual role could source to harm the vagina [37].

\section{Conclusions}

Vaginitis is an imperative infection of females cause inflammation of vagina and vulva. It also causes discharge, itching and pain. During the study high number of cases $22(36 \%)$ were recorded in age group B: 21 25 years while the lowest ratio of cases $2(3 \%)$ were recorded in age group G: $46-50$ years. Also it was further noted that married females were more infected than nonmarried, i.e. $54(87 \%)$ and $8(13 \%)$ respectively. The mentioned infection is considering as a confidential issue of females in Pakhtun society. Awareness and further study is recommended regarding vaginitis.

\section{Authors' contributions}

Conceived and designed the experiments: S Mehmood, Performed the experiments: Nabeela, Analyzed the data: S Zaib, Contributed reagents/ materials/ analysis tools: M Rizwan, Wrote the paper: Muhammad.

\section{References}

1. Vaginal Health Organization (2010). Vaginal Yeast Infections Diagnosis, Treatment, and Prevention.

2. Diseases and Conditions Vaginitis Basics Definition February 6, 2009.

3. Vaginitis Definition Last Updated: June 30, 2009.

4. Trichomoniasis (2010). Gale: Contemporary Women's Issues. Healthy Women.

5. Satterwhite CL, Torrone E \& Meites E (2013).Sexually transmitted infections among US women and men: prevalence and incidence estimates. Sex Transm Dis 40: 187-193.

6. Sutcliffe S, Newman SB \& Ahardick (2010). Prevalence and correlates of Trichomonas vaginalis infection among female US federal prison inmates. Sex Transm Dis 37:585-590.

7. Klausner JD, Baer JT \& Contento KM (1999). Investigation of a suspected outbreak of vaginal trichomoniasis among female inmates. Sex Transm Dis 26:335338.

8. Ginocchio CC, Chapin K \& Smith JS (2012). Prevalence of Trichomonas vaginalis and Co infection with Chlamydia trachomatis and Neisseria gonorrhoeae in the United States as Determined by the Aptima Trichomonas vaginalis Nucleic Acid Amplification Assay. J Clin Microbiol 50: 2601-8.

9. Gaydos CA, Hsieh YH \& Barnes M (2011). Trichomonas vaginalis infection in women who submit self-obtained vaginal samples after internet recruitment. Sex Transm Dis 38: 828-32.

10.Cu-Uvin S, Ko H \& Jamieson DJ (2002). Prevalence, incidence, and persistence or recurrence of trichomoniasis among human immunodeficiency virus (HIV)-positive women and among HIV negative women at high risk for HIV infection. Clin Infect Dis 34:1406-1411.

11.Schwebke JR \& Burgess D (2004). Trichomoniasis. Clin Microbiol Rev17: 794-803.

12.Krieger JN, Jenny C \& Verdon M (1993). Clinical manifestations of trichomoniasis in men. Ann Intern Med 118: 844-849.

13. McClelland RS, Sangare L \& Hassan WM (2007). Infection with Trichomonas vaginalis increases therisk of HIV-1 acquisition. J Infect Dis 195:698-702.

14.Pol VD, Kwok BC \& Pierre-LouisB (2008). Trichomonas vaginalis infection and human immunodeficiency virus acquisition in African women. J Infect Dis 197: 548-54.

15. Cotch MF, Pastorek JG \& Nugent RP (1997). The Vaginal Infections and Prematurity Study Group. Trichomonas vaginalis associated with low birth weight and preterm delivery. Sex Transm Dis 24:353-360.

16. Grodstein F, Goldman MB \& Cramer DW (1993). Relation of tubal infertility to history of sexually transmitted diseases. Am J Epidemiol 137: 577-584.

17. Paisarntantiwong R, Brockmann S \& Clarke L (1995). The relationship of vaginal trichomoniasis and pelvic inflammatory disease among women colonized with Chlamydia trachomatis. Sex Transm Dis 22:344-7.

18. Hill GB (1993). The microbiology of bacterial vaginosis. Am J Obstet Gyneacol 169: 450-454. 
19. Kent HL (1991). Epidemiology of vaginitis. Am J Obstet Gyneacol 165: 1168-1176.

20. McCue JD (1989). Evaluation and management of vaginitis. An update for primary care practitioners. Arch Interm Med 149:565-568.

21. Sobel JD (1997). Vaginitis. New Engl J Med 337: 1896-1903.

22. Foxman B \& Muraglia R (2013). Prevalence of recurrent vulvovaginal candidiasis in 5 European countries and the United States: Results from an internet panel survey. J of Lower Genital Tract Disease 17: 340-345.

23. Hatcher R (2004). Contraceptive technology. 18th ed. New York: Ardent Media, Inc 602.

24. Iavazzo C (2011). Boric acid for recurrent vulvovaginal candidiasis: The clinical evidence. Journal of Women's Health 20:1245.

25. Vaginal Health Organization (2010). Vaginal Yeast Infections Diagnosis, Treatment, and Prevention.

26. Centers for Disease Control and Prevention (2002). STD treatment guidelines. Available: http://www.cdc.gov/std/treatment/

27. Lennox JA, Abbey SD, Udiba D, Mboto CI,Ikpoh IS \& Akubuenyi FC (2013). Prevalence of vaginitis and vaginosis among University of Calabar female students. Journal of Public Health and Epidemiology 5(4): 167-172.

28. Roberta BN, Kevin EK, Sharon LH, David ES, Carol AS, Richard LS, Peter R \& Holly ER (2005). A Cluster Analysis of Bacterial Vaginosis-associated Microflora and Pelvic Inflammatory Disease. Am J Epidemiol162: 585-590.

29. Sobel JD (2007). Vulvovaginal candidosis. The Lancet 369:1961-1971.

30. Venugopal S, Gopalan K, Devi A \& Kavitha A (2017). Epidemiology and clinico-investigative study of organisms causing vaginal discharge, Indian J Sex Transm Dis 38(1): 69-75.

31. Koumans EH, Sternberg M, Bruce C, McQuillan G, Kendrick J \& Sutton M (2007). The prevalence of bacterial vaginosis in the United States, 2001-2004; associations with symptoms, sexual behaviors, and reproductive health. Sex Transm Dis 34: 864-9.

32. Pawanarkar J \& Chopra K (2004). Health and population - Prevalence of lower reproductive tract infection in infertile women. Perspect Issues 27:67-75.

33. Gupta N, Zahn MM, Coppens I, Joiner KA \&Voelker DR (2005). Selective disruption of phosphatidylcholine metabolism of the intracellular parasite Toxoplasma gondii arrests its growth. J BiolChem 280: 16345-16353.

34. Nessa A, Nahar KN, Begum SA, Anwary SA, Hossain F and Nahar K (2013). Comparison between visual inspection of cervix and cytology based screening procedures in Bangladesh. Asian Pac J Cancer Prev 14: 7607-7611.

35. Janulaitiene M, Paliulyte V, Grinceviciene S, Zakareviciene J, Vladisauskiene A \& Pleckaityte M (2017). Prevalence and distribution of Gardnerella vaginalis subgroups in women with and without bacterial vaginosis. BMC Infect Dis 17: 394.

36. Rezaei AM, Shafiei S \& Zarei AM (2016).Isolation, molecular identification, and antifungal susceptibility profiles of vaginal isolates of Candida species. Iran J Microbiol 8(6): 410-417.

37. Chengo SM, Wahome E, Vaneechoutte M, Cools P, Crucitti T \& Eduard J (2017). High prevalence of curable sexually transmitted infections among pregnant women in a rural county hospital in Kilifi, Kenya. PLoS One 12(3): 195-199. 